\title{
Desain Antarmuka Sistem Informasi Sensus Harian Rawat Inap di Rs Krakatau Medika Cilegon
}

\author{
Tiara Diniah ${ }^{1}$, Rita Dian Pratiwi ${ }^{2}$ \\ Diploma III Rekam Medis, Sekolah Vokasi Universitas Gadjah Mada ${ }^{1,2}$ \\ tiarad23@yahoo.com ${ }^{1}$
}

\begin{abstract}
Diajukan 29 April 2019 Diperbaiki 16 Februari 2020 Diterima 26 Februari 2020
ABSTRAK

Latar Belakang: Pengolahan data sensus harian rawat inap (SHRI) di Rumah Sakit Krakatau Medika (RSKM) Cilegon dilakukan secara manual oleh perawat maupun pengolah data. Meskipun terdapat menu laporan SHRI di dalam Sistem Informasi Manajemen Rumah Sakit, pengolah data belum dapat menggunakannya dengan maksimal dikarenakan adanya kekurangan dan ketidaksesuaian dengan data yang diinginkan. Muncul ide bagi peneliti untuk merancang tampilan antarmuka sistem sensus harian rawat inap.

Tujuan: Mendesain antarmuka bagi pengguna sistem informasi sensus harian rawat inap berbasis web di RSKM.

Metode: Research and action dengan objek perancangan sistem informasi SHRI RSKM.

berbasis web yang didasari oleh observasi dan wawancara terhadap subjek.

Hasil: Berupa Diagram Konteks, Diagram Alir Data Level 1 serta tampilan Login, Halaman Utama Rawat Inap (RI), Halaman Utama Rekam Medis (RM). Halaman Utama RI terdapat tiga menu yaitu Register Rawat Inap, Informasi Ruang, dan Rekapitulasi, sedangkan Halaman Utama RM terdapat satu menu yaitu Laporan.

Kesimpulan: Berdasarkan hasil analisis kebutuhan diketahui bahwa RSKM membutuhkan sistem informasi untuk kegiatan SHRI yang dapat memudahkan petugas dalam mencatat data SHRI serta membuat laporannya. Telah dibuat desain proses dan desain antarmuka yang sesuai dengan analisis kebutuhan.
\end{abstract} Perancangan tampilan antarmuka sistem informasi

Kata Kunci: desain antarmuka; sensus harian rawat inap; sistem informasi

\section{ABSTRACT}

Background: Inpatient daily census data processing at Krakatau Medika Hospital (KMH) Cilegon is done manually by nurses and data processing officers. Although there is a menu for inpatient daily census reports, the data have not been used maximally due to the lack of desired data. An idea is led to design inpatient daily census system interface.

Objectives: To design a web based interface inpatient daily census information system at KMH.

Methods: Research and action method with the object of designing KMH inpatient census information system. The design is based on observation and interviews with the subject.
Result: Produces Context Diagram, Data Flow Diagram Level 1 and interface designs such as Login, Inpatient Main Page, Medical Record Main Page. On Inpatient Main Page there are three menus, namely Inpatient Registration, Room Information, and Recapitulation. On Medical Record Main Page there is one menu, namely Reports.

Conclusion: Based on the results of the analysis, it is known that KMH requires an information system for SHRI activities that can facilitate the officers to process the SHRI data and making reports from it. Process design and interface design have been made according to the analysis.

Keywords: information system; inpatient daily census; interface design 


\section{PENDAHULUAN}

Rumah sakit sebagai penyelenggara pelayanan kesehatan menyediakan pelayanan rawat inap, rawat jalan, dan gawat darurat bagi perorangan secara paripurna (UU No. 44, 2009). Sebagai suatu institusi pelayanan kesehatan, rumah sakit dituntut untuk memberikan pelayanan yang berkualitas dan dapat memuaskan pelanggannya.

Kualitas pelayanan yang diberikan dapat menunjukkan baik atau buruknya mutu pelayanan rumah sakit. Mutu pelayanan kesehatan di rumah sakit akan terjamin jika didukung oleh data dan informasi yang baik dan akurat dalam bentuk laporan rumah sakit. Salah satu data yang berperan penting yang perlu dimiliki rumah sakit yaitu sensus harian rawat inap (SHRI).

Sensus harian pasien rawat inap memuat informasi semua pasien masuk, pindahan, dipindahkan, dan keluar baik dalam keadaan hidup maupun meninggal dunia selama 24 jam setiap harinya. Wajib bagi setiap bangsal untuk mengisi lembar sensus setiap harinya dan mengirimkan ke unit rekam medis untuk diproses menjadi informasi kesehatan (Budi, 2011). Selanjutnya data SHRI ini akan dijadikan rekapitulasi SHRI dan akan diolah sehingga menghasilkan suatu informasi.

Menurut Depkes RI (2005) rekapitulasi bulanan pasien rawat inap merupakan formulir perantara untuk menghitung dan merekap pasien rawat inap selama sebulan yang diterima dari masing-masing ruang rawat inap. Menurut Kurniawan et al (2010) data sensus harian digunakan sebagai sumber data dalam pembuatan indikator pelayanan rawat inap yang selanjutnya digunakan dalam perhitungan BOR, AvLOS, BTO dan TOI.

Berdasarkan hasil wawancara dengan petugas pengolah data di Unit Rekam Medis, pengolahan data SHRI memiliki proses yang panjang dan memerlukan tenaga yang banyak untuk mengerjakan pengolahan data terebut. Hal ini dikarenakan pengolahan datanya masih dilakukan secara manual, meskipun pada kenyataannya di RS Krakatau Medika memiliki
SIMRS yang di dalamnya sudah terdapat menu untuk laporan SHRI yang melitputi submenu data detail dan data rekapitulasi. Submenu data detail merupakan tampilan data mentah dari SHRI yang meliputi pasien masuk pasien pindahan, pasien dipindahkan, dan pasien pulang. Sedangkan pada submenu data rekapitulasi seharusnya merupakan tampilan untuk rekapitulasi dari data SHRI, namun sampai saat ini belum pernah digunakan karena terdapat kesalahan rumus di dalam sistem rumus. Oleh karena itu peneliti tertarik melakukan perancangan desain antarmuka sistem untuk sensus harian rawat inap. Perancangan desain antarmuka ini merupakan salah satu langkah yang penting apabila kedepannya akan dibuat sistem sensus harian rawat inap, dan akan sangat berpengaruh untuk pengguna dalam menggunakan sistem dengan baik.

\section{METODE PENELITIAN}

Perancangan ini menggunakan metode action and research dengan objek perancangan berupa sistem informasi sensus harian rawat inap di RS Krakatau Medika Cilegon. Jenis penelitian yang digunakan adalah deskriptif dengan pendekatan kualitatif dan rancangan penelitian studi kasus. Perancangan tampilan antarmuka sistem informasi sensus harian rawat inap berbasis web ini didasari oleh observasi dan wawancara terhadap subjek yang akan terlibat langsung dengan pemakaian sistem informasi sensus harian rawat inap.

\section{HASIL DAN PEMBAHASAN}

Hal yang pertama dilakukan oleh perancang dalam merancang produk tampilan ini adalah mengidentifikasi kebutuhan pengguna sistem yang berada di RS Krakatau Medika Cilegon. Menurut Abdelhak dan Hanken (2016) salah satu prinsip umum desain adalah kebutuhan pengguna yang mempertimbangkan kebutuhan pengguna (need of user) untuk mendesain antarmuka pengguna. Identifikasi kebutuhan dilakukan dengan observasi kegiatan SHRI dan 
mewawancarai subjek yang terlibat dalam observasi kegiatan sensusharian rawat inap: perancangan ini. Berikut merupakan tabel hasil

Table 1. Hasil Observasi

\begin{tabular}{|c|c|c|c|c|}
\hline No. & Objek yang Diamati & Ya & Tidak & Keterangan \\
\hline 1. & $\begin{array}{l}\text { Pengumpulan data sensus harian } \\
\text { rawat inap dilakukan secara manual } \\
\text { dengan mencatatnya pada formulir } \\
\text { SHRI. }\end{array}$ & $\mathrm{V}$ & & $\begin{array}{l}\text { Diambil oleh petugas } \\
\text { pengolah data dari setiap } \\
\text { ruang perawatan. }\end{array}$ \\
\hline 2. & SHRI dilakukan secara manual. & $\mathrm{V}$ & & \\
\hline 3. & $\begin{array}{l}\text { SHRI dilakukan secara } \\
\text { komputerisasi. }\end{array}$ & & V & \\
\hline 4. & $\begin{array}{l}\text { Ada petugas yang melakukan } \\
\text { pengolahan data SHRI. }\end{array}$ & $\mathrm{V}$ & & $\begin{array}{l}\text { Satu petugas, namun dibantu } \\
\text { oleh petugas lainnya. }\end{array}$ \\
\hline 5. & Data SHRI terdapat dalam SIMRS. & $\mathrm{V}$ & & $\begin{array}{l}\text { Data belum tentu sesuai } \\
\text { dengan kenyataannya. }\end{array}$ \\
\hline 6. & $\begin{array}{l}\text { Terdapat permasalahan pada hasil } \\
\text { output rekapitulasi SHRI pada SIMRS. }\end{array}$ & V & & $\begin{array}{l}\text { Permasalahannya pada } \\
\text { rumus. }\end{array}$ \\
\hline 7. & $\begin{array}{l}\text { Perhitungan indikator pelayanan } \\
\text { rumah sakit dilakukan pada Microsoft } \\
\text { Excel. }\end{array}$ & $\mathrm{V}$ & & $\begin{array}{l}\text { Oleh kepala Unit Rekam } \\
\text { Medis. }\end{array}$ \\
\hline 8. & $\begin{array}{l}\text { Pembuatan grafik Barber Johnson } \\
\text { dilakukan pada Microsoft Excel. }\end{array}$ & & $\mathrm{V}$ & $\begin{array}{l}\text { Menggunakan aplikasi } \\
\text { tersendiri. }\end{array}$ \\
\hline
\end{tabular}

Berdasarkan hasil wawancara diketahui bahwa pengumpulan data SHRI dilakukan secara manual yang diambil oleh petugas pengolah data dari setiap ruang perawatan. Cara pengumpulan yang masih manual dirasa kurang efektif karena mobilitas pasien yang tinggi.

Selain itu, cara pengolahan data SHRI pun masih dilakukan secara manual. Hal ini dikarenakan SHRI dalam bentuk komputerisasi belum dapat digunakan secara efektif dan maksimal. Pada penggunaan SHRI dalam bentuk komputerisasi terdapat permasalahan pada rumus di dalam SIMRS. Cara pengolahan data yang masih manual baik di ruang perawatan maupun di Unit Rekam Medis memerlukan proses/langkah yang panjang sehingga tidak efektif dan membutuhkan ketelitian yang besar dalam mengolahnya. Ditambah saat terjadinya human error pada saat megolah dataSHRI.

Alur kegiatan SHRI di ruang perawatan yang dimulai dari pasien masuk ruang perawatan, pencatatan data SHRI, dan pencatatan data rekapitulasi SHRI. Sedangkan

alur kegiatan SHRI di Unit Rekam Medis dimulai dari pengumpulan dari masingmasing ruang perawatan yang diambil oleh petugas pengolah data, proses pengolahan data SHRI, dan pembuatan laporan dari data SHRI oleh Kepala Unit Rekam Medis. Kendala yang terjadi saat melakukan pengolahan data SHRI di ruang perawatan yaitu pada saat adanya kesibukan masing-masing perawat sehingga pencatatan SHRI terhambat. Selain itu tidak terdapat admin bangsal pada ruang perawatan untuk melakukan kegiatan administrasi pasien, sehingga yang melakukan pekerjaan tersebut adalah perawat. Sedangkan kendala yang terjadi saat melakukan pengolahan data SHRI di Unit Rekam Medis yaitu pada saat menghitung rekapitulasi SHRI yang didapat dari lembar SHRI.

Dari analisis kebutuhan diketahui bahwa dibutuhkan suatu sistem sensus harian rawat inap untuk membantu kelancaran proses pencatatan data SHRI, rekapitulasi SHRI, dan pembuatan laporan yang bersumber dari data SHRI. Berikut merupakan gambaran diagram konteks sebagai dasar untuk menyusun 


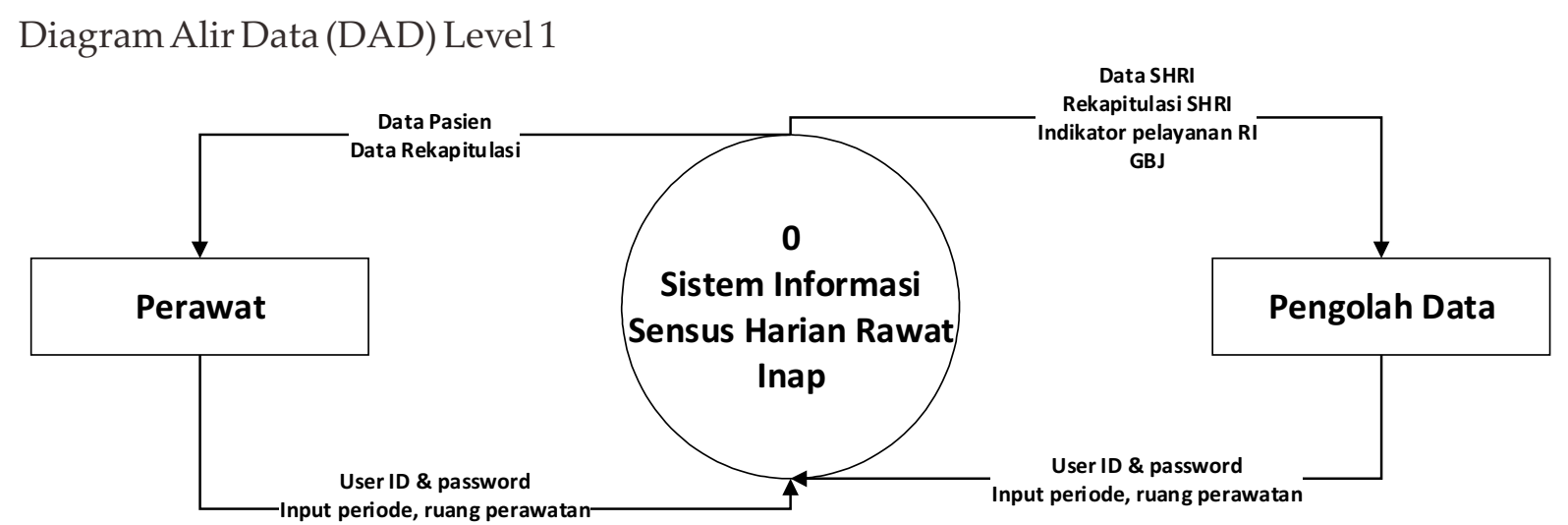

Input data pasien

Gambar 1. Diagram Konteks

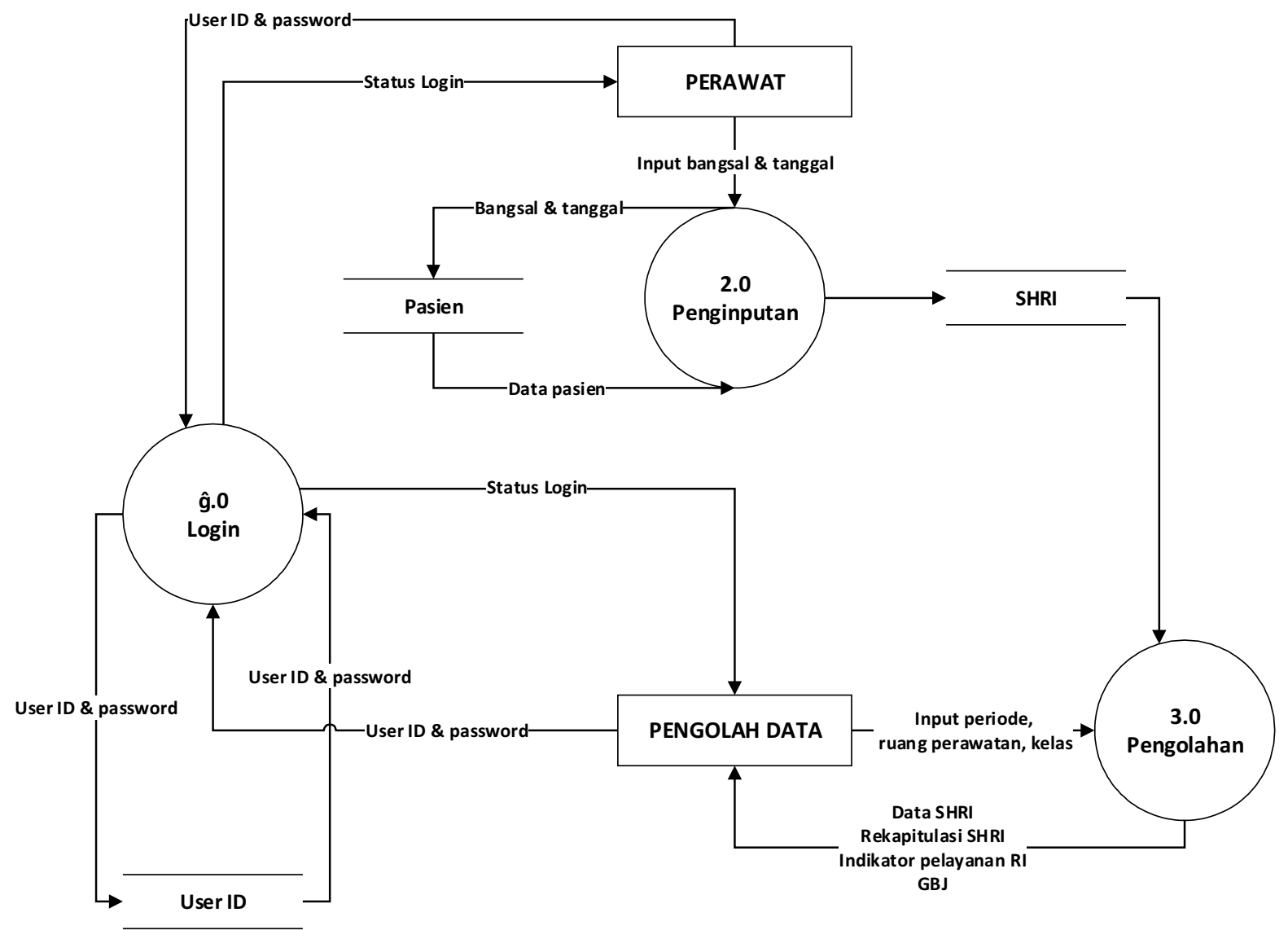

Gambar 2. DAD Level 1

Selain itu dihasilkan 28 buah tampilan untuk sistem informasi sensus harian rawat inap, dan terdapat tiga halaman utama, yaitu Login, Halaman Utama Rawat Inap (RI), dan Halaman Utama Rekam Medis (RM). Berikut merupakan gambaran dari masing-masing tampilan:

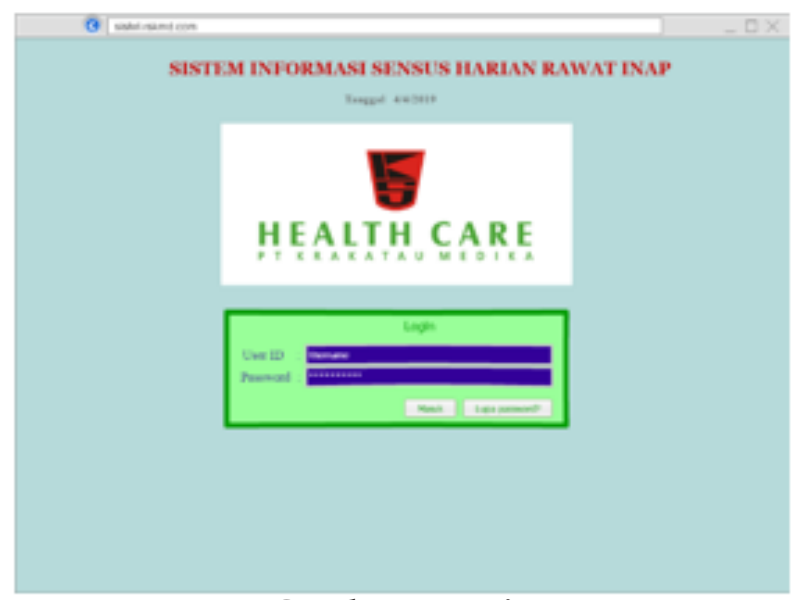

Gambar 3. Login 
Halaman utama Login terdiri user ID, password, tombol masuk, dan tombol lupa password. User ID diinput dengan username pengguna, dan password diinput dengan kata sandi pengguna. Tombol masuk diklik untuk memasuki sistem informasi, dan tombol Lupa Password diklik apabila pengguna lupa dengan kata sandi miliknya.

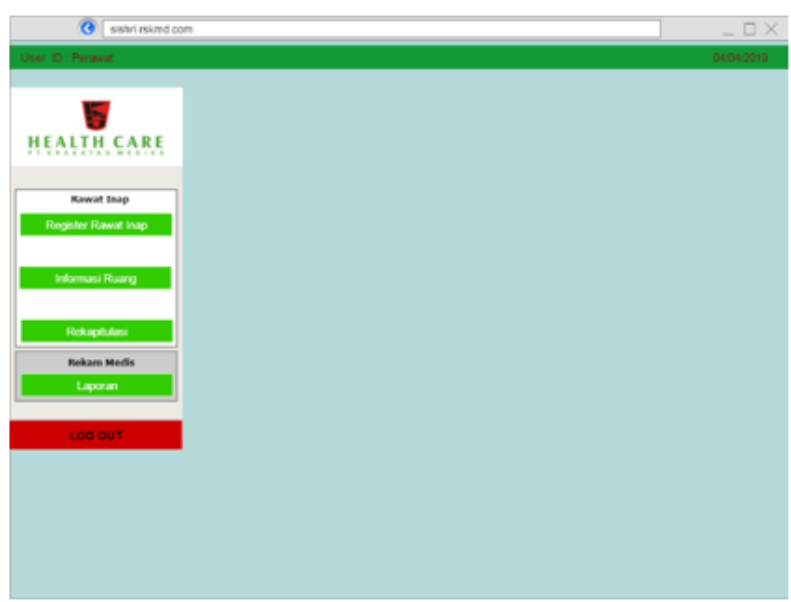

\section{Gambar 4. Halaman Utama RI}

Pengguna yang dapat menggunakan Halaman Utama RI adalah perawat. Menu yang dapat digunakan yaitu Register Rawat Inap, Informasi Ruang, dan Rekapitulasi.

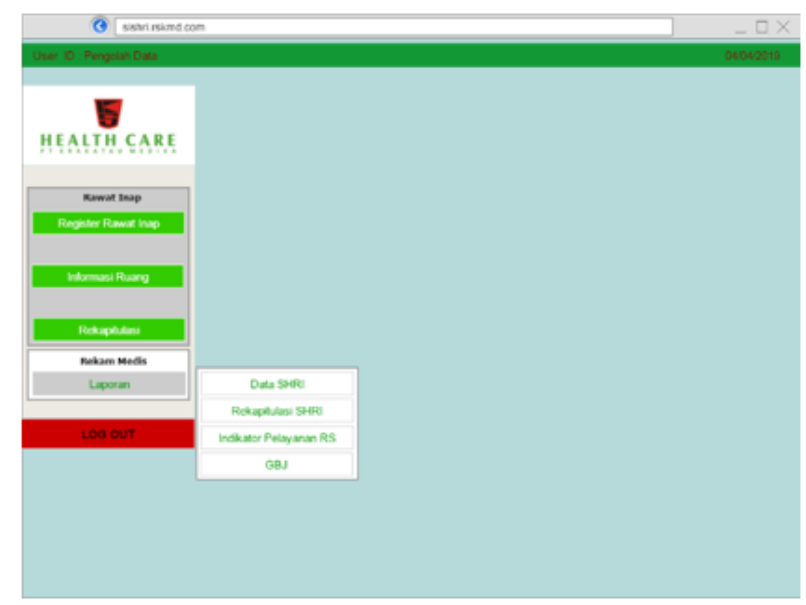

Gambar 5. Halaman Utama RM

Pengguna yang dapat menggunakan Halaman Utama RM adalah petugas pengolah data. Menu yang teraktivasi yaitu Laporan. Di dalam menu Laporan terdapat empat submenu yaitu Data Sensus Harian Rawat Inap (SHRI), Rekapitulasi SHRI, Indikator Pelayanan RI, dan Grafik Barber Johnson. Berikut merupakan hasil tampilan untuk masing-masing submenu menu Laporan:

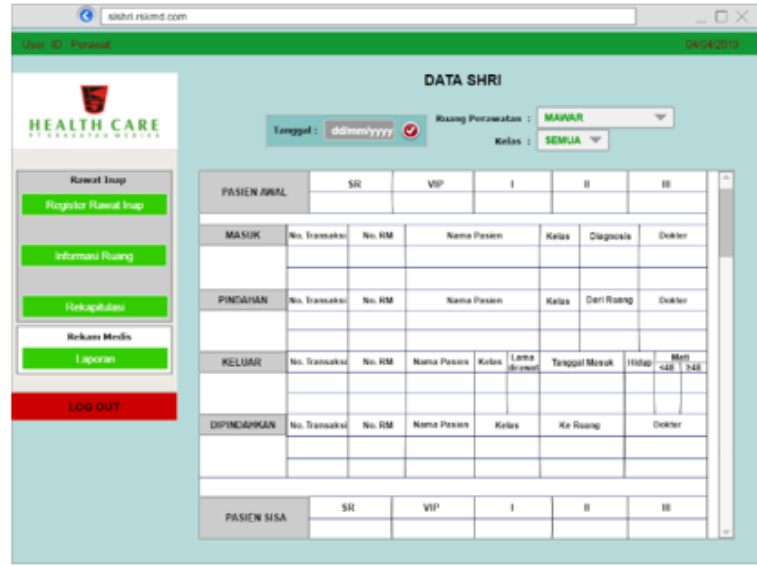

Gambar 6. Submenu Data SHRI

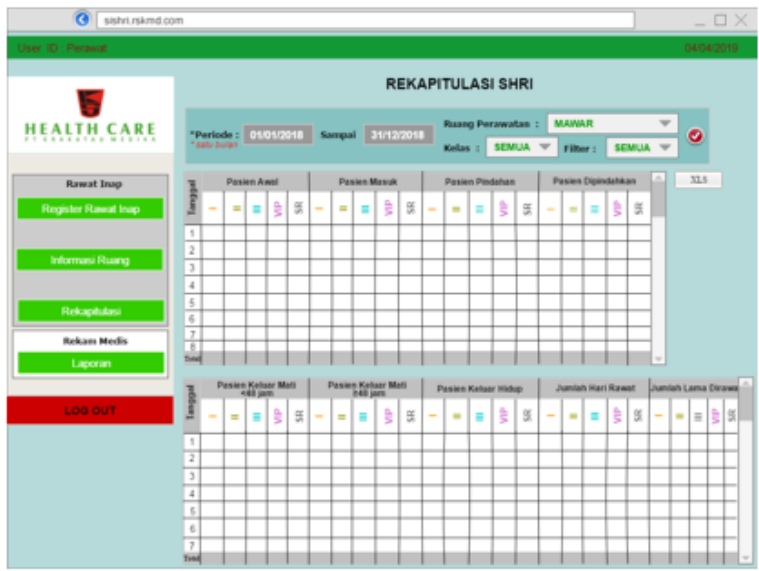

Gambar 7. Submenu Rekapitulasi SHRI

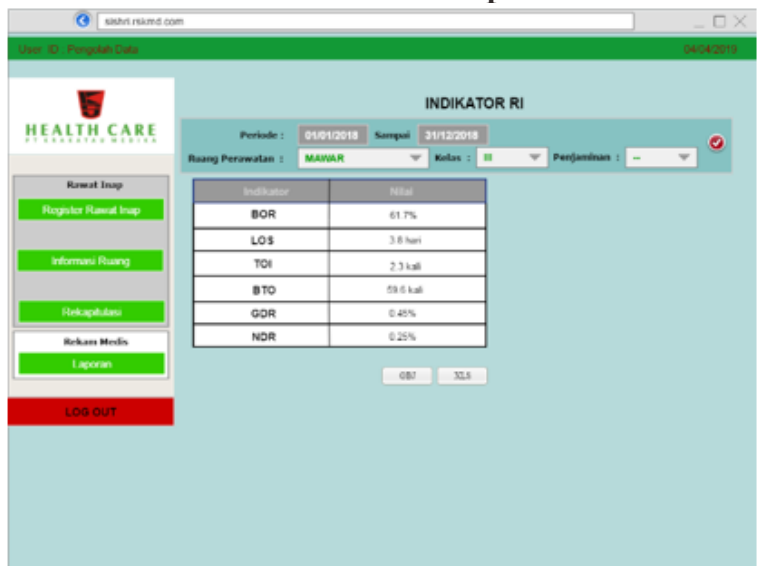

Gambar 8. Submenu Indikator Pelayanan RI

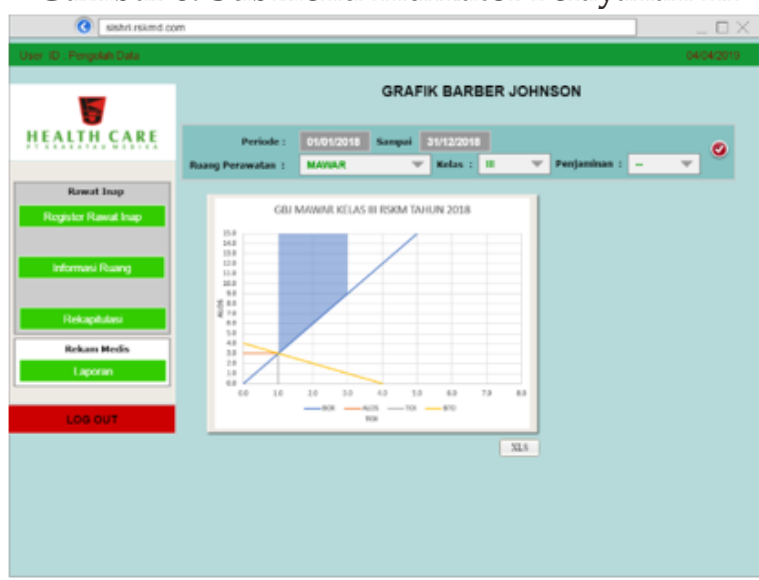

Gambar 9. Submenu Grafik Barber Johnson 
Data yang digunakan untuk membuat tampilan menu tidak berbeda jauh dengan yang terdapat pada lembar sensus harian rawat inap, seperti pasien masuk, pasien pindahan, pasien dipindahkan, pasien keluar hidup, pasien keluar mati $<48$ jam, pasien keluar mati $\geq 48$ jam, dan sebagainya. Hal ini sesuai dengan yang dijelaskan dalam Permenkes RI Nomor 1171 tahun 2011 tentang Petunjuk Teknis Sistem Informasi Rumah Sakit bahwa di dalam formulir data kegiatan pelayanan rawat inap memuat pasien awal tahun, pasien masuk, pasien keluar hidup, pasien keluar mati $<48$ jam, pasien keluar mati $\geq 48$ jam, jumlah lama dirawat, pasien akhir satu tahun, jumlah hari perawatan.

\section{KESIMPULAN DAN SARAN}

Dalam penelitian ini, telah dihasilkan desain antarmuka sesuai dengan analisis kebutuhan pada kegiatan sensus harian rawat inap baik di ruang perawatan maupun di Unit Rekam Medis. Perancangan sistem informasi ini menghasilkan dua desain proses yang meliputi diagram konteks dan DAD level 1, sedangkan untuk perancangan antarmuka dihasilkan 28 tampilan, dimana terdapat tiga halaman utama yang meliputi Login, Halaman Utama RI, dan Halaman Utama RM. Pada masing-masing halaman utama terdapat beberapa menu dan submenu didalamnya. Terdapat hak akses juga bagi pengguna, yaitu apabila pengguna merupakan perawat Halaman Utama RI akan terbuka dan dapat digunakan, dan Halaman Utama RM tidak dapat digunakan. Sebaliknya apabila pengguna meruapakan pengolah data Halaman Utama RM akan terbuka dan dapat digunakan, dan Halaman Utama RI tidak dapat digunakan.

Saran yang dapat diberikan yaitu perancangan antarmuka sistem informasi sensus harian rawat inap ini diharapkan dapat dijadikan pertimbangan untuk pembuatan dan pengembangan sistem informasi selanjutnya.

\section{DAFTAR PUSTAKA}

Abdelhak, M. \& Hanken, M.A. (2016).H e a $1 \mathrm{t} \mathrm{h}$ information:management of a strategic resource. In Health Information: management of a strategic resource $(\mathrm{p}$. 771 ). $\underline{\mathrm{htt} p: / / \mathrm{doi} .0 \mathrm{rg} / 10.1111 / \mathrm{j} .1439}$ 0310.1995.tb00895.x.

AHIMA. (2014). AHIMA's Long-Term Care Health Information Practice and Documentation Guidelines . Diakses pada 28 Januari 2020 dari https://library.ahima.org/Pages/ /link.as px? id=897A285877244DB6A2F11CF531 F8BC5D\& $\mathrm{z}=\mathrm{Z}$

Budi, S. C. (2011). Manajemen Unit Kerja Rekam Medis. Yogyakarta: Quantum Sinergis Media.

Caine, Kelly et al. (2015). “Designing a PatientCentered User Interface for Access Decisions about EHR Data: Implications from Patient Interviews." Journal of General Internal Medicine 30(S1): 7-16. http://link.springer.com/10.1007/s11606014-3049-9.

Capan, M., Hoover, S., Jackson, E. V., Paul, D., \& Locke, R. (2016). Time series analysis for forecasting hospital census: Application to the neonatal intensive care unit. Applied clinical informatics, 7(02), 275289.

Direktorat Jenderal Bina Pelayanan Me dik. (2005). Buku Petunjuk P e n g i s i a n, Pengolahan dan Penyajian Data Rumah Sakit. Jakarta: D e p a $\mathrm{r} t \mathrm{e} m$ e $\mathrm{n}$ Kesehatan Republik Indonesia.

Direktorat Jenderal Bina Upaya Kesehatan. (2011). Juknis SIRS 2011. Jakarta: Departemen K e s e h a t a $\mathrm{n}$ Republik Indonesia.

Kurniawan, A., Lestari, T., dan Rohmadi. (2010). Analisis Pemanfaatan Data Sensus Harian Rawat Inap Untuk Pelaporan Indikator Pelayanan $\mathrm{R}$ a w a $\mathrm{t}$ Inap di Rumah Sakit Umum D a e r a h Dr. Soeroto Ngawi. Jurnal Kesehatan, ISSN 1979-9551.4 
(2): 62-86.

Menkes RI. (2009). Undang-Undang RI Nomor 44 Tahun 2009 tentang $\mathrm{R} \mathrm{u} \mathrm{m}$ a h Sakit. www.depkes.go.id. Diakses tanggal 28 Februari 2019.

Miharti, R. dan Rohmasari, D. R. (2018). Kebutuhan Pengguna dalam Perancangan Disain Antarmuka SIMRS RSU 'Aisyiyah Ponorogo. Jurnal Kesehatan Vokasional. 3 (2): 81-89

RS Krakatau Medika Cilegon. (2017). Pedoman Pela yan a $\mathrm{R}$ e k a m M ed is. Cilegon:Unit Rekam Medis RS Krakatau
Medika Cilegon.

Septiani, M. (2017). Perancangan Basis Data untuk Sistem Informasi Sensus $\mathrm{H}$ a $\mathrm{r}$ i a $\mathrm{n}$ Rawat Inap Berbasis Web di $\mathrm{R} \mathrm{u} \mathrm{m} \mathrm{a} \mathrm{h}$ Sakit Umum Aisyiyah Ponorogo. Tugas Akhir.Program Diploma III Rekam Medis \& Informasi $\mathrm{K}$ e s e $\mathrm{h}$ a $\mathrm{t}$ a $\mathrm{n}$ Sekolah Vokasi UGM, Yogyakarta.

Yen, P. Y., \& Bakken, S. (2012). Review of health information technology usability study methodologies. Journal of the American Medical Informatics Association, 19(3), 413-422. 